\title{
Constraints Faced by the Members of Farmer Producer Company
}

\author{
S. L. Chopade, P.S. Kapse and V.G. Dhulgand* \\ Department of Extension Education, VNMKV, Parbhani. (M. S.), India \\ *Corresponding author
}

\section{A B S T R A C T}

\begin{tabular}{|l|}
\hline Ke y w o r d s \\
Constraints, \\
$\begin{array}{l}\text { Members of farmer } \\
\text { producer company, } \\
\text { Suggestions. }\end{array}$ \\
\hline Article Info \\
\hline $\begin{array}{l}\text { Accepted: } \\
\text { 20 July 2019 } \\
\text { Available Online: } \\
\text { 10 August } 2019\end{array}$ \\
\hline
\end{tabular}

\section{Introduction}

Agriculture remains the largest source of livelihood in Indian economy. About 45 per cent Indian population depend on agriculture for employment. In India role of small farms (and small holdings) in poverty reduction is well recognized (Lipton, 2006 However, in the absence of robust public/private support system at the ground level farmers face challenges in accessing land, water, inputs, credit, technology and market. Then, there are emerging challenges like risk and vulnerabilities due to climate change and natural calamities (Thapa and Gaiha, 2011).

FPO's are Collectivization of producers, especially low and marginal farmers, into the producer organization has come out as one of the most efficient pathways to address the many challenges of agriculture, but more significantly, improved approach to investments, technology and inputs and markets. Department of Agriculture and Cooperation, Ministry of Agriculture, Govt. of India has identified farmer, producer organization registered under the particular provisions of the Companies Act, 1956 as the most appropriate institutional form around which to mobilize farmers and establish their capacity to jointly leverage their production and selling effectiveness.

The basic purpose envisioned for the FPOs is to collectivize small farmers for backward linkage for inputs like seeds, fertilizers, credit, insurance, knowledge and extension services; and forward linkages such as collective 
marketing, processing, and market-led agriculture production (Mondal, 2010).

\section{Materials and Methods}

The present study was conducted in Osmanabad district, randomly selected from Marathwada region of Maharashtra state during the year 2018-2019. Selected district eight tahsils were selected purposively. From Osmanabad district, Osmanabad blocks were selected purposively based on considerable number of respondent as a member of 'Farmer Producer Company'. From one selected blocks, 3 villages were selected randomly based on considerable number of members of Farmer Producer Company. From each selected village, 40 farmers were selected randomly. In this way a total of 120 farmers were considered as respondent for the present study. These selections were done by using simple random sampling method for the purpose of the study. For the objective of constraints faced by the farmers in seeking the information about farmers' producer organization. Ex-post facto research design was adopted in this study. The data were collected with the help of pretested interview schedule. The statistical methods and tests such as frequency and percentage were used for the analysis of data.

Constraints faced by the farmers in seeking the information about farmers' producer organization

\section{Results and Discussion}

Constraints faced by the farmers in seeking the information about farmers' producer organization

It was observed from Table 1 that, 72.86 per cent of respondents reported that noninclusion of local leaders in FPC's, 69.28 percent of respondent reported that lack of coordination for different group activities, 55.00 percent of respondent reported that lack of support from the government department after establishment of FPC's, 40.00 percent of respondent reported that political affiliation of member, 30.71 percent of respondent reported that bank are not very much familiar of concept of FPC's, these companies have limited access to banks, 21.43 percent of respondent reported that inadequate profit to individual members and 10.71 percent of respondent reported that village level worker not providing enough information about all scheme related to FPC's.

\section{Suggestions of the respondents to overcome the constraints in seeking the information about the FPC}

It was observed that 67.14 per cent of respondent have suggested that wide publicity should be given to the concept of FPC's for increasing awareness amongst the farmers, 50.71 percent of respondent were suggested that the management team of FPC, should share information about FPC's with member farmers, 44.28 per cent of respondent were suggested that the success stories of FPC's should be given wide media publicity, 25.71 per cent of respondent were suggested that state government need to extend all the benefits of farmer co-operatives, 21.43 per cent of respondent were suggested that the agencies involved in implementing the FPC initiative should provide adequate information about their venture, 17.14 per cent of respondent were suggested that regular trainings should be given to member of FPC's about agro-based processing units and marketing of agriculture produce and 15.71 per cent of respondent were suggested that the concept of FPC's should be explained in easy language. 
Table.1 Constraints faced by the farmers in seeking the information about farmers' producer organization

\begin{tabular}{|c|c|c|c|}
\hline $\begin{array}{l}\text { Sr. } \\
\text { No. }\end{array}$ & Constraints & Frequency & Percentage \\
\hline 1. & Non- inclusion of local leaders in FPC's & 102 & 72.86 \\
\hline 2. & Lack of co-ordination for different group activities & 97 & 69.28 \\
\hline 3. & $\begin{array}{l}\text { Lack of support from the government department } \\
\text { after establishment of FPC's }\end{array}$ & 77 & 55.00 \\
\hline 4. & Political affiliation of member & 56 & 40.00 \\
\hline 5. & $\begin{array}{l}\text { Bank are not very much familiar of concept of FPC's } \\
\text { these companies have limited access to banks. }\end{array}$ & 43 & 30.71 \\
\hline 6. & Inadequate profit to individual members & 30 & 21.43 \\
\hline 7. & $\begin{array}{l}\text { Village level worker not providing enough } \\
\text { information about all scheme related to FPC's }\end{array}$ & 15 & 10.71 \\
\hline
\end{tabular}

Table.2 Suggestion to overcome the constraints as perceived by the respondents in seeking the information about the FPC

\begin{tabular}{|c|l|c|c|}
\hline Sr. No. & \multicolumn{1}{|c|}{ Suggestions } & Frequency & Percentage \\
\hline $\mathbf{1 .}$ & $\begin{array}{l}\text { Wide publicity should be given to the concept of } \\
\text { FPC's for increasing awareness amongst the } \\
\text { farmers }\end{array}$ & 94 & $\mathbf{6 7 . 1 4}$ \\
\hline $\mathbf{2 .}$ & $\begin{array}{l}\text { The management team of FPC, should share } \\
\text { information about FPC's with member farmers }\end{array}$ & 71 & $\mathbf{5 0 . 7 1}$ \\
\hline $\mathbf{3 .}$ & $\begin{array}{l}\text { The success stories of FPC's should be given wide } \\
\text { media publicity }\end{array}$ & 62 & $\mathbf{4 4 . 2 8}$ \\
\hline $\mathbf{4 .}$ & $\begin{array}{l}\text { State government need to extend all the benefits of } \\
\text { farmer co-operatives }\end{array}$ & 36 & $\mathbf{2 5 . 7 1}$ \\
\hline $\mathbf{5 .}$ & $\begin{array}{l}\text { The agencies involved in implementing the FPC } \\
\text { initiative should provide adequate information } \\
\text { about their venture }\end{array}$ & 30 & $\mathbf{2 1 . 4 3}$ \\
\hline $\mathbf{6 .}$ & $\begin{array}{l}\text { Regular trainings should be given to member of } \\
\text { FPC's about Agro-based processing units and } \\
\text { marketing of agriculture produce }\end{array}$ & 24 & $\mathbf{1 7 . 1 4}$ \\
\hline $\mathbf{7 .}$ & $\begin{array}{l}\text { The concept of FPC's should be explained in } \\
\text { easy language }\end{array}$ & $\mathbf{2 2}$ & $\mathbf{1 5 . 7 1}$ \\
\hline
\end{tabular}


The conclusions of the study are as follows:

1. Majority $(72.86 \%)$ of respondents reported that non- inclusion of local leaders in FPC's as major constraints was found FPC's members.

2. Majority (67.14\%) per cent of respondent were suggested that wide publicity should be given to the concept of FPC's for increasing awareness amongst the farmers

\section{References}

Agarwal B. (2010). Rethinking agricultural production collectivities. Economic \& Political Weekly, February 27, 2010. 55 (9): 64-78.

Ahire, R.D. (2000). A Study on the Consequences of Watershed Development Programme. Ph.D. Thesis, Marathwada Agriculture University, Parbhani.

Ahire, R.D. and P. S. Kapse (2015). Socioeconomic Impact of Commodity Interest Group among Pomegranate Growers. Agresco Report 2014-2015 VNMKV, Parbhani.

Aitwadw,N.M., (2017).Impact of Shri Hanuman Sahakari Dudh Vyvasayik Krishi Purak Sanstha Maryadit, Yalgad: A case study, PhD. (Agri.) Thesis, MPKV Rahuri

Ampaire, E. L., Machethe, C. L., Birachi, E. (2013). The role of rural producer organizations in enhancing market participation of smallholder farmers in Uganda: Enabling and disabling factors. African Journal of Agricultural Research, 8(11): 963-970.

Asante, B.,Victor, A.S and Daniel, S. 2011.Determinants of small scale farmers' decision to join farmer based organizations in Ghana. African Journal of Agricultural Research. 6: 2273-2279

Bhandari, S.D. (2014). Socio-economic impact of Mahatma Gandhi national rural employment guarantee act on the beneficiaries. M.Sc. (Agri.) Thesis, Vasantrao Naik Marathwada Krishi Vidyapeeth, Parbhani (Maharashtra).

Bhosale, J.S. (2014). Impact of integrated pest management technology in cotton on beneficiary farmers of farmers field school. M.Sc. (Agri.) Thesis, Dr. Panjabrao Deshmukh Krishi Vidypeeth, Akola (Maharashtra).

Garg, S.K., S.K. Badodiya, O.P. Daipuriya and Rawat, U. (2012). Impact of Swarnjayanti Gram Swarozgar Yojna on poverty alleviation in Morar block of Gwalior district. Indian Research Journal of Extension Education (I), pp: 189-191.

Khalache, P.G. and Gaikwad, J.H. (2011). Impact of watershed development programme of watershed organization trust (WOTR) on the beneficiaries in Ahmednagar district. Indian Journal of Extension Education (47), No. 3 \& 4, pp: 104-108.

Khandave, S.R. and Suryawanshi P.S. (2015). Impact of National Horticulture Mission on beneficiaries. J. Agric. Res. Technol. 40 (2), pp: 348-350.

Mankar, D.M., P.P. Wankhade and Shambharkar, Y.B. (2013). Impact of National Horticulture Mission on its beneficiaries. International Journal of Exten. Edu. (9), pp: 72-80.

Mankar, D.M., P.P. Wankhade and Kale, N.M. (2014). Socio-economic impact of improved Soybean technology on farmers. International J. Exten. Edu. (10), pp: 146152.

\section{How to cite this article:}

Chopade, S.L., P.S. Kapse and Dhulgand, V.G. 2019. Constraints Faced by the Members of Farmer Producer Company. Int.J.Curr.Microbiol.App.Sci. 8(08): 2358-2361. doi: https://doi.org/10.20546/ijcmas.2019.808.273 